\title{
In vitro evaluation of copaiba oil as a kojic acid skin enhancer
}

\author{
Robson Vicente Machado de Oliveira ${ }^{1 *}$, Mitsuko Taba Ohara ${ }^{2}$, Marta Maria Duarte Carvalho \\ Vila $^{1}$, Marcos Moisés Gonçalves ${ }^{3}$
}

\begin{abstract}
${ }^{1}$ Pharmacology Course, Sorocaba University, ${ }^{2}$ Pharmacology Department, Faculty of Pharmaceutical Sciences, University of São Paulo, ${ }^{3}$ Department of Analytical Chemistry, Chemistry Institute, State University of Campinas
\end{abstract}

\begin{abstract}
The capacity of copaíba oil to act as a skin penetration enhancer for the depigmenting agent kojic acid was evaluated using an in vitro diffusion system with static flux and shed rattlesnake skin membrane, Crotalus durissus terrificus, in saline solution at $34 \pm 2{ }^{\circ} \mathrm{C}$ as the fluid receptor. The quantities of kojic acid liberated into the fluid receptor were determined by spectrophotometry at $268 \mathrm{~nm}$ with intervals of one and a half hours. The membranes, pretreated with copaíba oil at $25 \%$ and $50 \% \mathrm{v} / \mathrm{v}$, gave flux values of 8.0 and $12.7 \mu \mathrm{g} / \mathrm{cm}^{2} / \mathrm{h}$, permeability values of 2.0 and $3.3 \mathrm{~cm} \times 10^{-4} / \mathrm{h}$, and promotion factors of 4.1 and 3.7, respectively. These results indicate that copaíba oil, at the two concentrations studied, has the capacity to promote penetration of kojic acid.
\end{abstract}

Uniterms: Copaíba oil. Kojic acid. Skin penetration/ in vitro studies .UV Spectrophotometry.

\begin{abstract}
A propriedade do óleo de copaíba como agente promotor de penetração cutânea do despigmentante ácido kójico foi avaliada utilizando-se sistema de difusão in vitro com fluxo estático, membrana de pele da serpente cascavel - Crotalus durissus terrificus e solução salina a $34 \pm 2{ }^{\circ} \mathrm{C}$ como fluido receptor. As quantidades liberadas do ácido kójico no fluido receptor foram determinadas por espectrofotometria em $268 \mathrm{~nm}$ em intervalos de 1:30 h. As membranas pré-tratadas com óleo de copaíba a $25 \mathrm{e} 50 \% \mathrm{v} / \mathrm{v}$ apresentaram valores de fluxo de 8,0 e $12,7 \mu \mathrm{g} / \mathrm{cm}^{2} / \mathrm{h}$, permeabilidade de 2,0 e $3,3 \mathrm{~cm} \times 10^{-4} / \mathrm{h}$, e fatores de promoção de 4,1 e 3,7, respectivamente. Os resultados obtidos indicaram que o óleo de copaíba, nas duas concentrações estudadas, apresentou capacidade de promoção da penetração do ácido kójico.
\end{abstract}

Unitermos: Óleo de copaíba. Ácido kójico. Penetração cutânea/ in vitro. Espectrofotometria UV.

\section{INTRODUCTION}

Hyper pigmentation of the skin can be caused by a range of factors such as aging, pregnancy, endocrine disturbances, hormonal treatment and sun exposure to varying degrees. Several substances are commonly employed as depigmentation agents in the manufacture of cosmetics used for the reduction of hyper pigmentation, one of these being kojic acid (Cabanes, Garcia-Carmona, 1994; Su, 1999; Nicoletti et al., 2002). Kojic acid (5-hydroxy-2-(hydroxymethyl)-4-pirone) is a depigmenting agent obtained from rice fermentation (Burdock et al., 2001) as a fungus metabolite from the genera Aspergillus and Penicillym, and acts by inhibiting tyrosinase activity

\footnotetext{
*Correspondence: R.V. M. Oliveira. Curso de Farmácia, Universidade de Sorocaba. Rodovia Raposo Tavares, Km 92,5 - 18023-903 - Sorocaba - SP, Brasil. E-mail: robson.oliveira@prof.uniso.br
}

(Cabanes, Garcia-Carmona 1994).

In order to be effective, depigmenting agents incorporated in topical formulas must cross the stratum corneum to act on the more inner layers situated towards the basal lamina of the epidermis. To this end, the addition of other compounds with a greater capacity for skin penetration, also known as absorption promoters or "enhancers", can result in an increase in diffusion of substances by disorganizing the lamellas of the stratum corneum (Williams, Barry, 2004). The incorporation of these substances in formulations allows for the development of topical products with a lower concentration of active ingredients, thereby increasing both the efficacy and safety of the product (Yourik, Bronaugh, 1999).

Various species of Brazilian flora such as copaiba are being investigated for their industrial potential in the formulation of cosmetics and medications (Veiga Junior et al., 2007; Stupp et al., 2008). Copaibas are frequently cited 
as a source of ingredients possessing anti inflammatory, anti infectious, anti tumoral and wound healing properties, among others (Veiga Junior, Pinto, 2002). Copaibas are trees that are native to the tropical regions of Latin America and Western Africa, belonging to the family Leguminosae Juss, sub-family Caesalpinoideae Kunth. These trees furnish an oily substrate consisting of 40 to $50 \%$ essential oil and 40 to $60 \%$ resin, whose composition is made up principally of esters and terpenes (Cascon, Gilbert, 2000; Pinto et al., 2000; Biavati et al., 2006).

Copaiba oil, given its terpine compounds such as sesquiterpenes, oxygenated sesquiterpenes, hydrocarbon diterpenes and oxygenated diterpenes (Pinto et al., 2000) is a good choice as a permeability promoter for other compounds. Terpenic compounds are well known for their ability to increase cutaneous penetration (El-Kattan et al., 2001; Narishetty, Panchagnula, 2004).

In vivo and in vitro (Franz et al., 1993) diffusion methods are used to study the efficacy of skin penetrating agents. For in vitro methods, diffusion cells or the Franz method are used where, in the literature, many studies have used diffusion cells with membranes from the skin of rats, mice, guinea pigs, shed snake skin, human or synthetic skin to assess the penetration promoting powers of different substances (Franz et al.., 1993; Bronaugh, Collier, 1993). Different experimental conditions involving modifications of temperature, agitation, different pretreatment temperatures, collection of samples and trial duration have been described (Akimoto, Nagase, 2003; Andega et al., 2001; Babu, Pandit, 2004; Cotte et al., 2004; El-Kattan et al., 2001).

The use of shed snake skin as a membrane in in vitro systems is justified due to the similarities between shed snake skin and the stratum corneum of human skin, in terms of structure, lipid composition, water permeability, and other substances with different functional groups. (Itoh et al., 1990). Additionally, shed snake skin has advantages in terms of low cost, ease of use, absence of hair, and lack of need to sacrifice animals. (Lin et al., 1992; Haigh et al., 1998; Chang, Zheng, 2003).

For the above reasons and due to the need to investigate properties of vegetable compounds, the aim of this study was to evaluate in vitro, copaiba oil as a penetrating agent for kojic acid in a shed snake skin model through diffusion studies in an effort to develop more effective topical depigmenting agents.

\section{MATERIAL AND METHODS}

\section{Material}

Substances used were AP grade, kojic acid was
$90 \%$ purity and the solutions were prepared using freshly distilled water. Copaiba oil was of pharmaceutical purity and was kindly donated by Ionquímica. The membranes used as diffusion cells were obtained from the shed skin of the rattle snake Crotalus durissus terrificus.

\section{Methods}

\section{Preparation of membranes}

Square or rectangular sections measuring about $4 \mathrm{~cm}$ per side were cut from the ventral part of the shed snake skin, containing four sections of rigid scales and three flexible sections. These were placed in distilled water at room temperature for 48 hours to hydrate. The membranes were then dried on absorbent paper and placed in a receptacle with an external diameter of about $3.7 \mathrm{~cm}$, and an area available for diffusion of $3.14 \mathrm{~cm}^{2}$.

\section{Quantification of kojic acid in receptor fluid}

Quantification of the kojic acid was done by spectrophotometry (Beckman-Coulter ${ }^{\circledR}$ DU-640) at $268 \mathrm{~nm}$ (Oliveira et al., 2007) using a method adapted from Majmudar and collaborators (1998). This method gave a quantification limit of $0.17 \mu \mathrm{g} / \mathrm{mL}$ and a detection of $0.057 \mu \mathrm{g} / \mathrm{mL}$ according to Oliveira and collaborators (2007).

Readings were taken from $0.5 \mathrm{~mL}$ aliquots of the fluid receptor after dilution up to $10 \mathrm{~mL}$ with saline solution (sodium chloride $0.9 \% \mathrm{p} / \mathrm{v}$ ) and filtration through a $0.45 \mu \mathrm{m}$ pore membrane.

\section{Diffusion Assays}

The (Logan ${ }^{\circledR}$ SDFC-6 VTC-200) in vitro cell diffusion system was used, composed of three vertical diffusion cells with donation compartments of $2 \mathrm{~cm}$ diameter, receptor compartments with a capacity of 15.0, 15.1 and $15.2 \mathrm{~mL}$, a support stand, and a magnetic agitation system equipped with a pump system and water heater.

The circulating water temperature was adjusted to $34 \pm 2{ }^{\circ} \mathrm{C}$ and the fluid receptor (saline solution) was maintained under agitation at $100 \mathrm{rpm}$.

Diffusion studies were carried out by applying saturated solutions of kojic acid with pretreatment of the membranes using oil solutions, and then quantifying the amount of kojic acid in the samples, extracted at different time intervals. (Colipa, 2000). Installed membranes were treated with $0.8 \mathrm{~mL}$ of saline solution initially and after 30 minutes were removed with the help of cotton. In the first cell, another $0.8 \mathrm{~mL}$ of saline solution was added and in the second cell, $0.8 \mathrm{~mL}$ of copaiba oil at $25 \%$ dilution in isopropyl - propylene glycol 95:5 v/v alcohol, and in the third, $0.8 \mathrm{~mL}$ of copaiba oil diluted in 50\% isopropyl - pro- 
pylene glycol 95:5 v/v. alcohol. After one hour, the solutions were removed with cotton and the membranes washed with distilled water. The first cell of the receptor compartment containing $15.1 \mathrm{~mL}$, received $0.8 \mathrm{~mL}$ of saline solution (white) while the second $(15.0 \mathrm{~mL})$ and third $(15.2 \mathrm{~mL})$ both received $0.8 \mathrm{~mL}$ of kojic acid $3.9 \% \mathrm{p} / \mathrm{v}$ equivalent to 31.2 $\mathrm{mg}$ of kojic acid. The experiment was run for $22 \mathrm{~h} 30 \mathrm{~min}$, with removal of aliquots and replacement of the volumes of the receptor compartments at times points $0 ; 1: 30 ; 3: 00$; $4: 30 ; 6: 00 ; 7: 30 ; 9: 00 ; 10: 30 ; 12: 00 ; 13: 30$ and $22: 30$ hours. Concentrations for kojic acid were determined spectrophotometrically and these values used to calculate the diffusion parameters. Four replicates of each experiment were done; however, the first determinations of kojic acid gave results lower than the quantification limits due to the heterogeneity of the shed snake skin membrane, and therefore these first results were omitted for the calculation of the mean values.

The mean quantity of kojic acid by area was obtained using the mean circular membrane values and the kojic acid concentration. Concentration of kojic acid was obtained from the mean values of absorbency. Kojic acid liberation curves by membrane area $\left(\mathrm{cm}^{2}\right)$ against hours of treatment were constructed (Asbill, Michniak, 2000).

Flux $\left(\mu \mathrm{g} / \mathrm{cm}^{2} / \mathrm{h}\right)$ was considered equal to the inclination coefficient of those lines with a linear correlation coefficient that yielded values greater than 0.9.

Permeability, which was equivalent to the depth of the membrane the substance managed to penetrate $(\mathrm{cm})$ against time (h), was calculated by dividing the flux values $\left(\mu \mathrm{g} / \mathrm{cm}^{2} / \mathrm{h}\right)$ by the kojic acid solution concentration $\left(39 \mathrm{mg} / \mathrm{cm}^{3}\right.$ ) applied to the membrane (Asbill, Michniak, 2000).

The latency time (hours), indicating the moment the membrane allowed Constant liberation of kojic acid, was extrapolated from the point where the regression lines crossed the axis of the abscissa (Barry, 1987).

To compare the effect on the oil solutions and their controls, a "promotion factor" calculated based on the mean flux $\left(\mu \mathrm{g} / \mathrm{cm}^{2} / \mathrm{h}\right)$ of kojic acid in the sample divided by the mean flux of the control (without pretreatment with oil) (Bronaugh, Collier, 1993).

\section{Statistical Analysis}

Fisher's and Student's $t$ tests were used to compare the data, means and standard deviations (Bussab, Morettin, 1985; Botter et al., 1996).

\section{RESULTS AND DISCUSSION}

The quantification of kojic acid began only from the three hour time interval in membranes treated with both 25 and $50 \%$ solutions of copaiba oil giving mean liberation values per area of 20.6 and $27.4 \mu \mathrm{g} / \mathrm{cm}^{2}$, respectively (see Table I). Prior to this three hour time point, the kojic acid concentration did not reach the quantification limit for the method employed (Oliveira et al., 2007). The solution of kojic acid 3.9\% p/v used in these penetration studies, with a $\mathrm{pH}$ around 4.0, favored the non ionized form of kojic acid, and allowing its penetration into the membranes.

Compared with the controls, membranes pretreated with oil solutions of 25 and $50 \%$ allowed better diffusion of kojic acid from the seven and one half hour time point, and after 12 hours the amounts of kojic acid liberated were $80.2 \mu \mathrm{g} / \mathrm{cm}^{2}$ and $135.2 \mu \mathrm{g} / \mathrm{cm}^{2}$, respectively (Table I). The lines associated to these oil solutions present greater inclination indicating a larger angular coefficient, and thus a higher flux (Figures 1 and 2). Figures 1 and 2 also show variable coefficients of correlation which can be explained by the irregular thickness and tortuosity inherent to the snake membrane (Ostrenga et al., 1974). The characteristics of animal membranes also influence the values of the variation coefficients. Lopes (1999), in his study of diffusion with sodium diclophenate on treatment with $0.2 \%$ papain solution in human membranes, found a coefficient of variation of up to $73 \%$ in the liberated amounts. Sato and colleagues (2007) also observed high standard deviations in their studies assessing kojic acid formula penetration in porcine skin membrane.

Based on the regression lines in the diffusion curves (Figures 1 and 2), the flux parameters, permeability parameters and latency time were extrapolated, as shown in Table II. The table demonstrates that latency times for the constant liberation of kojic acid were reduced with increased copaiba oil concentration. This represents a beneficial characteristic for depigmentation agents. The promotion factors for liberation of kojic acid obtained from treatment with $25 \%$ and $50 \%$ copaiba solutions $\mathrm{v} / \mathrm{v}$ were equivalent to 4.0 and 3.7 , values greater than those obtained from control solutions.

Analysis of the mean flux values shows that a 50\% distilled water solution may provide improved shed snake skin membrane hydration allowing for greater penetration of kojic acid. Copaiba oil was diluted in isopropyl alcohol associated with propylene glycol $(95: 5) \mathrm{v} / \mathrm{v}$, in a bid to ascertain the most powerful solvent, combined with preservation of integrity and humidification of the membrane and thus less interference in diffusion results owing to liberation of contaminants. Propylene glycol usually acts as a penetration promoter for substances and was therefore included in the controls (Larrucea et al., 2001). However, this same effect was not confirmed in the present study using snake skin membrane. Comparisons of kojic acid 
TABLE I - Kojic acid liberation in diffusion studies using shed snake skin membrane treated with 25 or $50 \% \mathrm{v} / \mathrm{v}$ copaiba oil solutions $(\mathrm{COS})$ or 25 or $50 \%$ distilled water (DW) in isopropyl-propylene glycol $(95: 5 \mathrm{v} / \mathrm{v})$ alcohol after application of kojic acid solution $3.9 \% \mathrm{p} / \mathrm{v}$

\begin{tabular}{|c|c|c|c|c|c|c|c|}
\hline \multirow{3}{*}{ Time (hours) } & \multirow{3}{*}{ Pre-treatment } & \multicolumn{6}{|c|}{ Quantity liberated by area $\left(\mu \mathrm{g} / \mathrm{cm}^{2}\right)$} \\
\hline & & \multicolumn{3}{|c|}{ Copaíba $25 \%$} & \multicolumn{3}{|c|}{ Copaíba 50\% } \\
\hline & & $\mathrm{n}$ & Mean & $\mathrm{SD}$ & $\mathrm{N}$ & Mean & SD \\
\hline \multirow[t]{2}{*}{$3: 00$} & DW & - & --- & --- & - & --- & --- \\
\hline & $\cos$ & 1 & 20.6 & --- & 2 & 27.4 & 3.1 \\
\hline \multirow[t]{2}{*}{$4: 30$} & DW & - & --- & --- & - & --- & --- \\
\hline & $\cos$ & 1 & 28.3 & --- & 3 & 44.2 & 18.8 \\
\hline \multirow[t]{2}{*}{$6: 00$} & DW & - & --- & --- & 2 & 18.4 & 0.8 \\
\hline & $\operatorname{cOS}$ & 1 & 41.3 & --- & 4 & 55.7 & 32.7 \\
\hline \multirow[t]{2}{*}{$7: 30$} & DW & - & --- & --- & 2 & 22.4 & 1.0 \\
\hline & $\mathrm{COS}$ & 3 & 31.2 & 21.2 & 4 & 71.9 & 38.1 \\
\hline \multirow[t]{2}{*}{ 9:00 } & DW & 3 & 19.0 & 2.0 & 3 & 26.2 & 5.9 \\
\hline & $\mathrm{COS}$ & 4 & 39.9 & 24.6 & 4 & 87.8 & 39.1 \\
\hline \multirow[t]{2}{*}{$10: 30$} & DW & 3 & 22.9 & 3.6 & 4 & 28.3 & 7.2 \\
\hline & $\mathrm{COS}$ & 4 & 63.8 & 43.7 & 4 & 118.9 & 58.4 \\
\hline \multirow[t]{2}{*}{$12: 00$} & DW & 3 & 27.2 & 1.7 & 4 & 34.8 & 9.9 \\
\hline & $\mathrm{COS}$ & 4 & 80.2 & 53.8 & 4 & 135.2 & 61.6 \\
\hline \multirow[t]{2}{*}{$13: 30$} & DW & - & --- & --- & 4 & 45.9 & 12.3 \\
\hline & $\mathrm{COS}$ & - & --- & --- & 4 & 161.9 & 74.5 \\
\hline \multirow[t]{2}{*}{$22: 30$} & DW & 4 & 46.2 & 13.4 & - & --- & --- \\
\hline & $\mathrm{COS}$ & 4 & 172.6 & 27.6 & - & --- & --- \\
\hline
\end{tabular}

COS - Copaiba Oil solution; DW - Distilled Water solution as control; SD - standard deviation ; ---not calculated ; $n$ - number of replicates

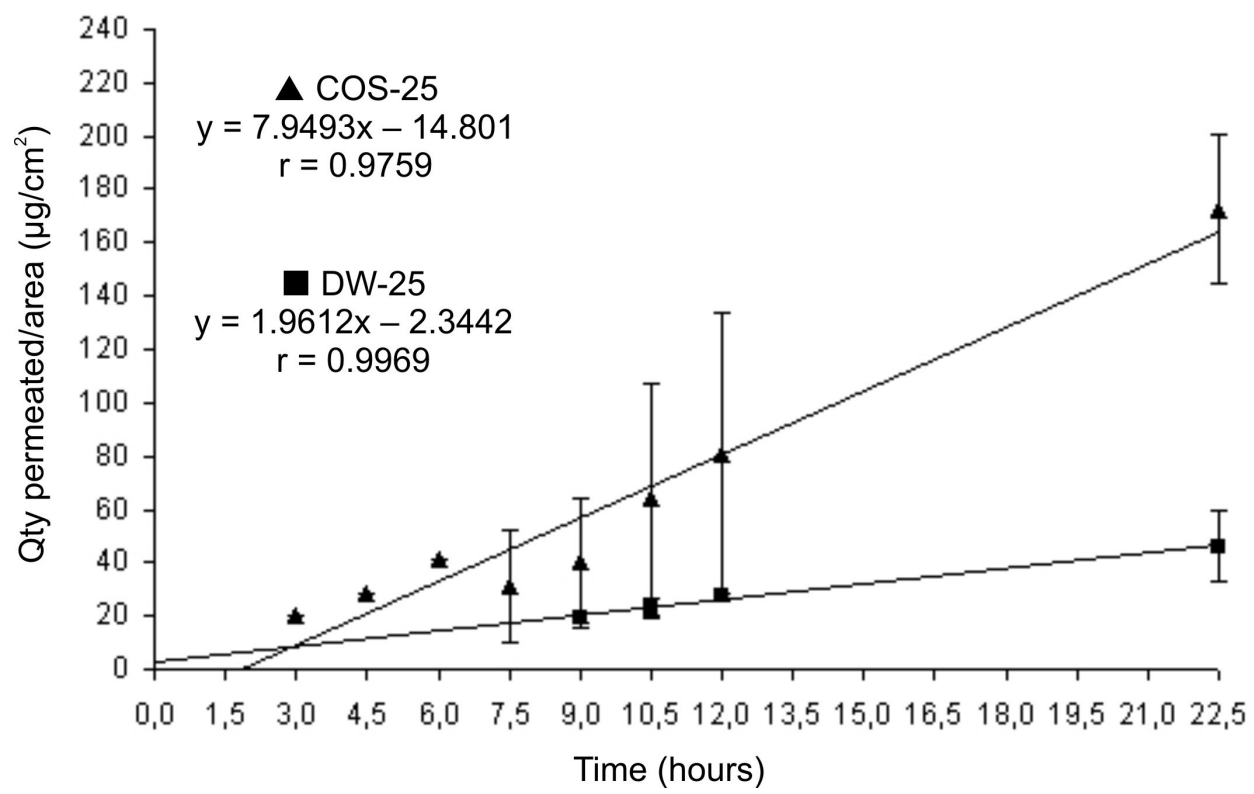

FIGURE 1 - Cutaneous diffusion profile in vitro of kojic acid in shed snake skin membrane treated with $25 \%$ copaiba oil in isopropylpropylene glycol $(95: 5 \mathrm{v} / \mathrm{v})$ alcohol solution $($ COS-25) or 25\% distilled water in isopropyl-propylene glycol $(95: 5 \mathrm{v} / \mathrm{v})$ alcohol solution (DW-25) and treated with kojic acid solution 3.9\% p/v. 


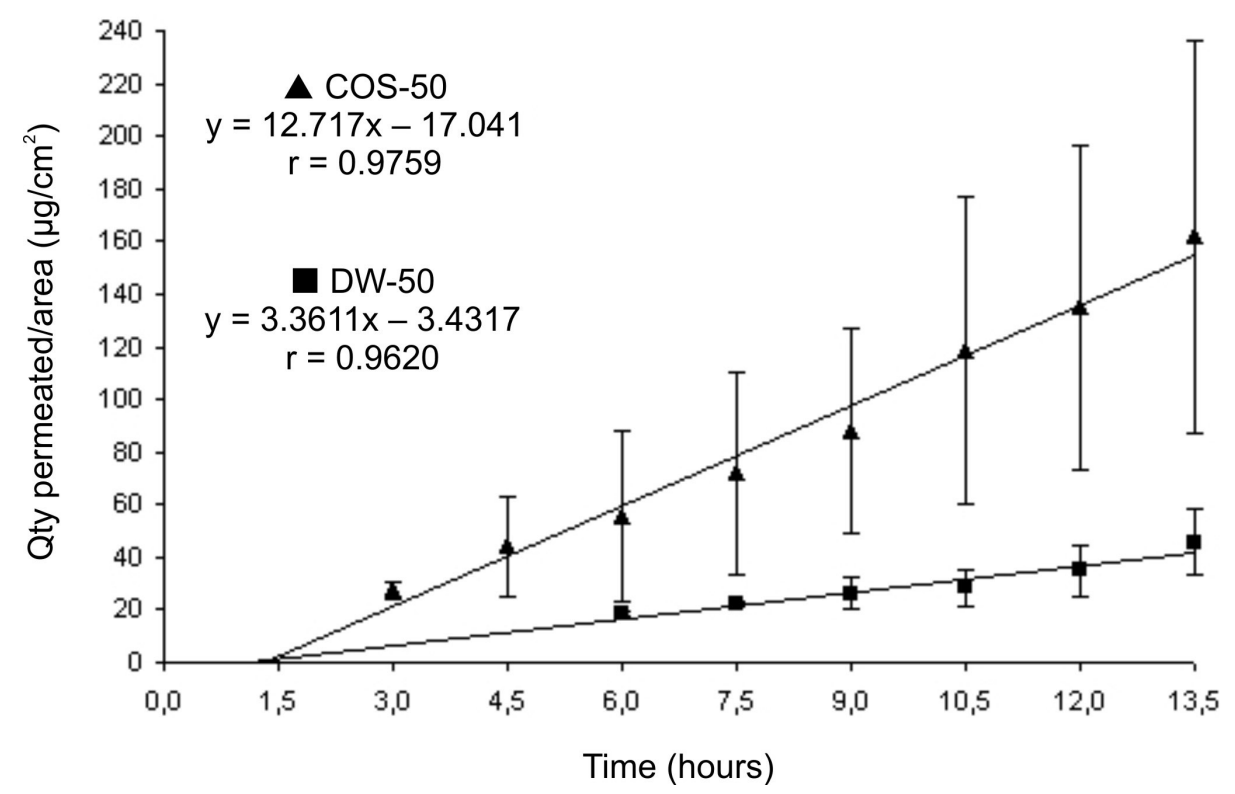

FIGURE 2 - Cutaneous diffusion profile in vitro of kojic acid in shed snake skin membrane treated with 50\% copaiba oil solution in isopropyl-propylene glycol (95:5 v/v) alcohol solution (COS-50) or in 50\% distilled water solution in isopropyl-propylene glycol $(95: 5 \mathrm{v} / \mathrm{v})$ alcohol solution (DW-50) and treated with kojic acid solution $3.9 \% \mathrm{p} / \mathrm{v}$.

TABLE II - Latency time (hours), flux $\left(\mu \mathrm{g} / \mathrm{cm}^{2} / \mathrm{h}\right)$ and permeability $(\mathrm{cm} / \mathrm{h})$ of kojic acid in diffusion studies of shed snake skin membrane treated with 25 or $50 \%$ copaiba oil solution in isopropyl-propylene glycol (95:5 v/v) alcohol (COS-25) or in 25 or $50 \%$ distilled water (DW) in isopropyl-propylene glycol (95:5 v/v) alcohol solution (DW-25) and treated with kojic acid solution 3.9\% p/v

\begin{tabular}{lccc}
\hline Treatment & Latency time (hours) & Mean Flux $\left(\mu \mathrm{g} / \mathrm{cm}^{2} / \mathrm{h}\right)$ & Mean Permeability $\left(\mathrm{cm} \mathrm{x} 10^{-4} / \mathrm{h}\right)$ \\
\hline DW-25 & - & 2.0 & 0.5 \\
COS-25 & $1: 50$ & 8.0 & 2.0 \\
DW-50 & $1: 20$ & 3.4 & 0.9 \\
COS-50 & $1: 00$ & 12.7 & 3.3 \\
\hline
\end{tabular}

COS - copaiba oil solution; DW - distilled water control; SD - standard deviation.

flux values from treatment studies versus those of controls revealed a decrease in these values at higher isopropyl alcohol concentrations.

Standard deviations were calculated from the means of the flux and permeability values extrapolated on the individual graphs of each replicate experiment, and for each copaíba oil concentration (Table III). Fisher's and Student's t values were obtained from these values and are displayed in Table IV.

Student's $t$ test revealed a significant difference in the mean flux values of kojic acid at the different copaiba oil concentrations on diffusion testing compared to the respective distilled water solutions. However, studies using 25 and $50 \% \mathrm{v} / \mathrm{v}$ solutions of copaiba oil showed no significant differences in the mean values of these parameters when compared with each other. These observations agree with the analysis of promotion factors which yielded similar values (3.7 and 4.0). Analysis using Fisher's test in these experiments found a significant difference in mean flux values, probably due to the shed snake skin membrane characteristic. Fisher's test also showed that the studies done with 25 and $50 \%$ distilled water in the treatment of snake skin membrane were homogeneous across all the experiments.

Comparing Fisher results for each experiment versus its respective control, only the $50 \% \mathrm{p} / \mathrm{v}$ copaíba oil solution produced a statistically significant variation for kojic acid flux. This shows that although test solutions and their controls were submitted to the same treatment, they did not show the same pattern of variation. This is largely due to irregularities in the snake skin membrane.

Shed snake skin was used as a membrane to facilitate the penetration of the test substances compared to the use of extracts of stratum corneum isolated from the skins, as 
TABLE III - Mean, standard deviation, variance and coefficient of variance for mean flux and mean permeability $\left(\mu \mathrm{g} / \mathrm{cm}^{2} / \mathrm{h}\right.$ and $\mathrm{cm} / \mathrm{h}$ ) of kojic acid from diffusion studies on shed snake skin membrane treated with 25 or $50 \%$ copaiba oil in isopropyl-propylene glycol $(95: 5 \mathrm{v} / \mathrm{v})$ alcohol solution (COS-25 or COS-50) or in 25 or 50\% distilled water in isopropyl-propylene glycol (95:5 v/v) alcohol solution (DW-25 or DW-50\%) and treated with kojic acid solution $3.9 \% \mathrm{p} / \mathrm{v}$

\begin{tabular}{cccccccccc}
\hline \multirow{2}{*}{ Experiment } & Pre-treatment & $\boldsymbol{N}$ & \multicolumn{3}{c}{ Flux $\left(\boldsymbol{\mu g} / \mathbf{c m}^{2} / \mathbf{h}\right)$} & \multicolumn{3}{c}{ Permeability $(\mathbf{c m} \mathbf{x} \mathbf{~ 1 0} / \mathbf{h})$} & \multirow{2}{*}{ CV\% } \\
\cline { 3 - 7 } & & & Mean & SD & $\mathbf{S}^{2}$ & Mean & SD & $\mathbf{S}^{2}$ & \\
\hline \multirow{2}{*}{1} & DW-25 & 3 & 2.369 & 0.979 & 0.959 & 0.607 & 0.251 & 0.063 & 41.34 \\
& COS-25 & 4 & 9.855 & 0.752 & 0.566 & 2.527 & 0.193 & 0.037 & 7.63 \\
2 & DW-50 & 4 & 4.665 & 0.953 & 0.909 & 1.196 & 0.244 & 0.060 & 20.43 \\
& COS-50 & 4 & 13.911 & 5.383 & 28.98 & 3.567 & 1.380 & 1.904 & 38.70 \\
\hline
\end{tabular}

$\mathrm{CV} \%$ - coefficient of variation; SD-standard deviation ; $\mathrm{S}^{2}$ - variance; $n$ - number of replicates

TABLE IV - Fisher's and Student's t test values for mean flux $\left(\mu \mathrm{g} / \mathrm{cm}^{2} / \mathrm{h}\right)$ of kojic acid in diffusion membrane studies using shed snake skin treated with 25 or 50\% copaiba oil in isopropyl -propylene glycol (95:5 v/v)alcohol solution (COS-25 or COS-50) or in 25 or $50 \%$ distilled water in isopropyl -propylene glycol (95:5 v/v) alcohol solution (DW-25 or DW-50\%) and treated with kojic acid solution $3.9 \% \mathrm{p} / \mathrm{v}$

\begin{tabular}{lcccccc}
\hline Experiments Compared & \multicolumn{3}{c}{$\boldsymbol{F}$ (Fisher's) } & \multicolumn{3}{c}{$\boldsymbol{t}$ (Student's) } \\
\cline { 2 - 7 } & DF & Tabled & Calculated & DF & Tabled & Calculated \\
\hline COS-25 and DW-25 & 2 and 3 & 9.55 & 1.70 & 5 & 2.571 & $11.525^{*}$ \\
COS-50 and DW-50 & 3 and 3 & 9.28 & $31.89 *$ & 6 & 2.447 & $3.383^{*}$ \\
COS-25 and COS-50 & 3 and 3 & 9.28 & $51.21^{*}$ & 6 & 2.447 & 1.493 \\
DW-25 and DW-50 & 2 and 3 & 9.55 & 0.95 & 5 & 2.571 & $3.119^{*}$ \\
\hline
\end{tabular}

$\alpha=0.05 ; *$ statistically significant difference; DF- degrees of freedom

demonstrated in the study by Lin and colleagues (1992), which found permeability values 2 to 4 times higher in shed snake skin (Phyton molurus) than in isolated stratum corneum for sodium diclophenate, theophyline and benzoic acid ( $2 \mathrm{mg} / \mathrm{mL}$ or $0.2 \%$ in aqueous solution). The use of shed snake skin in a study of copaiba oil as a promoter of skin penetration for hydrophilic substances such as kojic acid, takes into consideration the fact that these membranes have a lower permeability coefficient (3.3 to 6.1 times) for these compounds, extending the time required to carry out the experiments. With regard to lipophilic compounds, these have a permeability coefficient close those of membranes obtained from human skin ( 0.9 to 1.8 times) (3.3 to 6.1 times) (Ngawhirunpat et al., 2006).

The percentage penetration of kojic acid for the initial amount applied was $1.63 \%$ for the $50 \%$ solution of copaiba oil after an interval of 13 and a half hours versus $1.74 \%$ for the $25 \%$ solution of copaiba oil after a 22 and a half hour interval. These findings indicate that the 50\% oil solution allowed almost the same level of kojic acid penetration but in a much shorter time frame. This indicated that a $50 \%$ concentration of copaiba oil may be optimal for developing topical formulations containing kojic acid.

\section{CONCLUSION}

Copaiba oil in both the 25 and $50 \%$ v/v solutions studied proved to be a penetration promotion factor of kojic acid in $3.9 \% \mathrm{v} / \mathrm{v}$ solution in the shed snake skin membranes Crotalus durissus terrificus compared to controls. The promotion factors were 4.0 and 3.7 for $25 \%$ and $50 \%$ copaiba oil solutions, respectively. These results allowed us to conclude that this oil has the potential to be added to topical formulations as a penetration promoter for active hydrophilic substances.

\section{ACKNOWLEDGEMENTS}

We would like to thank the Department for the Control and Production of Pharmaceuticals and Medications of the Medical Sciences Faculty of the University of São Paulo, where this work was conducted. 


\section{REFERENCES}

AKIMOTO, T.; NAGASE, Y. Novel transdermal drug penetration enhancer: synthesis and enhancing effect of alkyldisiloxane compounds containing glucopyranosyl group. J. Control. Release, v.88, p.243-252, 2003.

ANDEGA, S.; KANIKKANNAN, N.; SINGH, M. Comparison of the effect of fatty alcohols on the permeation of melatonin between porcine and human skin. J. Control. Release, v.77, p.17-25, 2001.

ASBILL, C.S.; MICHNIAK, B.B. Percutaneous penetration enhancers: local versus transdermal activity. Pharm. Sci. Technol. Today, v.3, p.36-41, 2000

BABU, R.J.; PANDIT, J.K. Effect of cyclodextrins on the complexation and transdermal delivery of bupranolol through rat skin. Int. J. Pharm., v.271, p.155-165, 2004.

BARRY, B.W. Mode of action of penetration enhancers in human skin. In: ANDERSON, J.M., KIM, S.W., (Eds.). Advances in drug delivery systems 3: Proceedings of the Third International Symposium on Recent Advances in Drug Delivery Systems. Salt Lake City: Elsevier, 1987. p.85-97.

BIAVATI, M.W.; DOSSIN, D.; DESCHAMPS, F.C.; LIMA, M.P. Análise de óleo-resinas de copaíba: contribuição para o seu controle de qualidade. Rev. Bras. Farmacogn., v.16, p.230-235, 2006.

BOTTER, D.A.; PAULA, G.A.; LEITE, J.G.; CORDANI, L.K. Noções de estatística: com apoio computacional (versão preliminar). São Paulo: IME-USP, 1996. 231 p.

BRONAUGH, R.L.; COLLIER, S.W. In vitro methods for measuring skin permeation. In: ZATZ, J.L., (Ed.). Skin permeation: fundamentals and application. Wheaton: Allured, 1993. p.93-110.

BURDOCK, G.A.; SONI, M.G.; CARABIN, I.G. Evaluation of health aspects of kojic acid in food. Regul. Toxicol. Pharmacol., v.33, p.80-101, 2001.

BUSSAB, W.O.; MORETTIN, P.A. Estatística básica: métodos quantitativos. 4.ed. São Paulo: Atual, 1985. 321 p.

CABANES, J.; GARCIA-CARMONA, F. Kojic acid, a cosmetic skin whitening agent, is a slow-binding inhibitor of catecholase activity of tyrosinase. J. Pharm. Pharmacol., v.46, p.982-985, 1994.
CASCON, V.; GILBERT, B. Characterization of the chemical composition of oleoresins of Copaifera guianensis Desf., Copaifera duckei Dwyer and Copaifera multijuga Hayne. Photochemistry, v.55, p.773-778, 2000.

CHANG, C.; ZHENG, R. Effects of ultraviolet B on epidermal morphology, shedding, lipid peroxide, and antioxidant enzymes in Cope's rat snake (Elaphe taeniura). $J$. Photochem. Photobiol., B, v.72, p.79-85, 2003.

COLIPA Guidelines - Scientific Committee on Cosmetic Products and Non-Food Products. Annex 10 - Guidelines for in vitro methods to assess percutaneous absorption of cosmetic ingredients. In: Notes of Guidance for Testing of Cosmetic Ingredients for their Safety Evaluation, Monograph SCCNFP/1321/00, EC. Brussels, 2000. p.77-85.

COTTE, M.; DUMAS, P.; BESNARD, M.; TCHORELOFF, P.; WALTER, P. Synchroton FT-IR microscopic study of chemical enhancers in transdermal drug delivery: example of fatty acids. J. Control. Release, v.97, p.269-281, 2004.

EL-KATTAN, A.F.; ASBILL, C.S.; KIM, N.; MICHNIAK, B.B. The effects of terpene enhancers on the percutaneous permeation of drugs with different lipophilicities. Int. $J$. Pharm., v.215, p.229-240, 2001.

FRANZ, T.J.; LEHMAN, P.A.; McGUIRE, E.L. In vivo methods for the assessment of percutaneous absorption in man. In: ZATS, J.L. (Ed.). Skin Permeation: fundamentals and application. Wheaton: Allured, 1993. p.73-92.

HAIGH, J.M.; BEYSSAC, E.; CHANET, L.; AIACHE, J.M. In vitro permeation of progesterone from a gel through the shed skin of three different snake species. Int. J. Pharm., v.170, p.151-156, 1998 .

ITOH, T.; XIA, J.; MAGAVI, R.; NISHIHATA, T.; RYTTING, J.H. Use of shed snake skin as a model membrane for in vitro percutaneous penetration studies: comparison with human skin. Pharm. Res., v.7, p.1042-1047, 1990.

LARRUCEA, E.; ARELLANO, A.; SANTOYO, S.; YGARTUA, P. Combined effect of oleic acid and propylene glycol on the percutaneous penetration of tenoxicam and its retention in the skin. Eur. J. Pharm. Biopharm., v.52, p.113-119, 2001.

LIN, S.Y.; HOU, S.J.; HSU, T.H.S.; YEH, F.L. Comparisons of different animal skins with human skin in drug percutaneous penetration studies. Methods Find. Exp. Clin. Pharmacol., v.14, p.645-654, 1992. 
LOPES, P.S. Influência da papaína e do óleo de pequi na penetração percutânea do diclofenaco de sódio. São Paulo, 1999. 148 p. [Dissertação de Mestrado. Faculdade de Ciências Farmacêuticas. Universidade de São Paulo].

MAJMUDAR, G.; JACOB, G.; LABOY, Y.; FISHER, L. An in vitro method for screening skin-whitening products. $J$. Cosmet. Sci., v.49, p.361-367, 1998.

NARISHETTY, S.T.K.; PANCHAGNULA, R. Transdermal delivery of zidovudine: effect of terpenes and their mechanism of action. J. Control. Release, v.95, p.367-379, 2004.

NICOLETTI, M. A.; ORSINE, E.M.A.; DUARTE, A.C.N.; BUONO, G.A. Hipercromias: aspectos gerais e uso de despigmentantes cutâneos. Cosmet. Tolet., Ed. Port., v.14 p.46-51, 2002.

NGAWHIRUNPAT, T.; PANOMSUK, S.; OPANASOPIT, P.; ROJANATA,T.; HATANAKA, T. Comparison of the percutaneous absorption of hydrophilic and lipophilic compounds in shed snake skin and human skin. Pharmazie, v.61, p.331-335, 2006.

OLIVEIRA, R.V.M.; OHARA, M. T.; GONÇALVES, M. M.; VILA, M. M. D. C. Quantificação de ácido kójico em estudos de permeação in vitro. Lat. Am. J. Pharm., v.26, p.576-581, 2007.

OSTRENGA, J.; STEINMETZ, C.; POULSEN, B.; YETT, S. Significance of vehicle composition. II. Prediction of optimal vehicle composition. J. Pharm. Sci., v.67, p.11801183, 1974.

PINTO, A.C.; BRAGA, W.F.; REZENDE, C.M.; GARRIDO, F.M.S.; VEIGA JÚNIOR, V.F.; BERGTER, L.; PATITUCCI, M.L.; ANTUNES, O.A.C. Separation of acid diterpenes of Copaifera cearensis Huber ex Ducke by flash chromatography using potassium hydroxide impregnated silica gel. J. Braz. Chem. Soc., v.11, p.355-360, 2000.
SATO, M.E.O.; GOMARA, F.; PONTAROLO, F.G.R.; ANDREAZZA, I.F.; ZARONI, M. Penetração cutânea in vitro do ácido kójico. Rev. Bras. Cienc. Farm., v.43, p.196203, 2007.

STUPP, T.; FREITAS, R. A.; SIERAKOWSKI, M. R.; DESCHAMPS, F. C.; WISNIEWSKI JR, A.; BIAVATTI, M. W. Characterization and potential uses of Copaifera langsdorfii seeds and seed oil. Bior. Tech., v.99, p.26592663, 2008.

SU, E. G. Formulando com branqueadores da pele. Cosmet. Tolet., Ed. Port., v.11, p.57-63,1999

VEIGA JUNIOR, V. F.; PINTO, A. C. O gênero Copaifera L. Quim. Nova, v.25, p.273-286, 2002.

VEIGA JUNIOR, V. F.; ROSAS, E.C.; CARVALHO, M.V.; HENRIQUES, M.G.M.O.; PINTO, A.C. Chemical composition and anti-inflammatory of copaiba oils from Copaifera cearensis Huber ex Ducke, Copaifera reticulata Ducke and Copaifera multijuga Hayne - A comparative study. J. Ethnopharmacol., v.112, p.248-254, 2007.

WILLIAMS, A.C.; BARRY, B.W. Penetration enhancers. $A d v$. Drug Delivery Rev., v.56, p.603-618, 2004.

YOURICK, J.J., BRONAUGH, R.L. (Eds.). Percutaneous penetration as it relates to the safety evaluation of cosmetic ingredients. In__: Percutaneous absorption - Drugs, cosmetics, mechanisms, methodology. 3.ed. New York: Marcel Dekker, 1999. p.659-671.

Received for publication on $04^{\text {th }}$ December of 2007. Accepted for publication on $13^{\text {th }}$ of January of 2010. 